\title{
Comparative Studies of the Aqueous and Ethanolic Extracts of Ocimum gratissimum and Gongronema latifolium Leaves on the invivo Antioxidant levels of Wistar Albino Rats
}

\author{
Okoli, P., Nwaka, A.C.*, Anene, I.N. \\ Department of Biochemistry, Chukwuemeka Odumegwu Ojukwu University, Anambra State, Nigeria. \\ *Corresponding author's email: andynwaka@yahoo.com
}

\begin{abstract}
This study comparatively investigated the effects of aqueous and ethanolic extracts of Ocimum gratissimum and Gongronema latifolium a mono or biherbal formula on invivo enzymatic and non-enzymatic antioxidants of male wistar albino rats after 28 days of treatment at various doses. In this study, a total of 42 rats were used and were placed in seven groups. The $\mathrm{LD}_{50}$ by oral administration carried out showed that the lethal dose for aqueous and the ethanolic extracts of $O$. gratissimum is greater than $5000 \mathrm{mg} / \mathrm{kg}$ and that of the aqueous and ethanolic extracts of $G$. latifolium is $3400 \mathrm{mg} / \mathrm{kg}$. Oral administration was $200 \mathrm{mg} / \mathrm{kg}$ body weight for monoherbal and $400 \mathrm{mg} / \mathrm{kg}$ body weight for the bi-herbal extracts. All value are expressed as mean \pm SD at $\mathrm{p}<0.05$ for various test groups against the control. The result above shows that there was no statistically significant difference between test groups and control group as determined by one-way ANOVA for Malondialdehyde, Vitamin E and Vitamin C. The activity of the enzymatic antioxidants like superoxide dismutase, glutathione peroxidase, catalase and that of the non-enzymatic antioxidant such as vitamin $\mathrm{E}$ and vitamin $\mathrm{C}$ of group 1, 2, $3,4,5$ and 6 were raised in rats fed with aqueous and ethanolic extract of $G$. latifolium and O. gratissimum leaf compared to the control which is group 7. From the study, it can be concluded that the G. latifolium extract showed greater effect on the invivo enzymatic and nonenzymatic antioxidant than the $O$. gratissimum leaf.
\end{abstract}

Original Research Article

Received: 9th Sept., 2017 Accepted: 10th Oct., 2017 Published: $23^{\text {rd }}$ Oct., 2017.

\section{Keywords:}

Gongronema latifolium;

Ocimum gratissimum;

Phytochemicals;

Acute toxicity;

Free radicals.

\section{INTRODUCTION}

$\mathrm{T}$

The perennial plant, Ocimum gratissimum (Scent leaf) is widely distributed in Africa and Asia. It belongs to the genus Ocimum. The phytochemical evaluation of this plant has shown that it is rich in alkaloid, flavonoids, phenolics, glycosides, saponins and tannins and oligosaccharides. The ethanolic extract contained majority of the active compounds like alkaloid, flavonoids, phenolics, glycosides, saponins and tannins while aqueous extract contain oligosaccharides and reducing sugar. It has tolerable cyanogenic content (Ijeh et al., 2004). The volatile aromatic oil from the leaves consist mainly of thymol (32-65\%) and eugenol. It also contains xanthones, terpenes and lactone (Ervanshings, 1986). Characteristics of its ethanolic extracts revealed the presence of non-cyclicsequesterpenes, phenols (Ervanshings, 1986). Oil from the leaves has been found to possess antiseptics, antibacterial and antifungal activities
(Ervanshings, 1986). It is used in the treatment of fungal infection, fever, cold and catarrh. Clinical trial in creams formulated against dermatological diseases have yielded favorable result (Edeoga and Eriata, 2001). Nutritional importance of this plant centers on its usefulness as a seasoning because of its aromatic flavour (Ervanshings, 1980). O. gratissimum have been reported to possess free radical scavenging (antioxidant properties (Ugochukwu et al., 2006, Akinmoladun et al., 2007). The presence of phenols has been reported in the ethanolic extract of the plant. Some of the pharmacological activities of the plant include antiseptics, antibacterial and anti-fungal and have been proved to be very effective microbial agent at low concentration (Ervanshings, 1986).

Gongronema Latifolium ("Utazi"), is a herbaceous shrub with yellow flowers and the stem that yields a characteristics milky exudates when cut. It belongs to the family 
Asclepiadaceae and known locally as "utasi" by the Efiks, Ibibios and Quas, "utazi" by the Igbos and "arokeke" by the Yoruba's in Nigeria. It is primarily used as spices vegetables in traditional folk (Ugochukwu and Babady, 2002). The phytochemical evaluation of this plant has shown that it is rich in alkaloid, flavonoids, phenolics, glycosides, saponins and tannins and oligosaccharides (Schneider et al., 1993; Morebise et al., 2002).

Free radicals including superoxide radical $\left(\mathrm{O}_{2}^{-}\right)$, hydroxyl radical $\left(\mathrm{OH}^{-}\right)$, hydrogen peroxide $\left(\mathrm{H}_{2} \mathrm{O}_{2}\right)$ and lipid peroxide radical are implicated in a situation where there are low activity of antioxidant and hyperlipidemia (Ugochukwu et al., 2003). These reactive oxygen species (ROS) are normal consequence of biochemical process formed from the mitochondria and endoplasmic reticulum of aerobic organisms as oxygen is being reduced along the electron transport chain in the body and also as a result of increased exposure environmental xenobiotics (Allian and Miller, 1996; Cook and Samman, 1996; Kumpulainen and Salonen, 1999). Many medicinal plants including G. Latifolium and $O$. gratissimum have been reported to possess free radical scavenging (antioxidant) properties (Ogundipe et al., 2003; Ugochukwu et al., 2003; Trevisan et al., 2006, Akinmoladun et al., 2007). They contain several different pharmacological active compounds that may act individually additively or synergistically to improve health.

Lipid hydro peroxides are non-radical intermediates derived from unsaturated fatty acids, phospholipids, glycolipids, cholesterol esters and cholesterol itself. Their formation occur in enzymatic or non-enzymatic reactions involving activated chemical species known as "reactive oxygen species" (ROS) which are responsible for toxic effects in the body via various tissue damages. These ROS include among others hydroxyl radicals, lipid or peroxyl radicals, singlet oxygen, and peroxinitrite formed from nitrogen oxide (NO), all these groups of atoms behave as a unit and are now named "free radical". These chemical forms are defined as any species capable of independent existence that contains one or more unpaired electrons (those which occupy an atomic or molecular orbital by themselves). They are formed either by the loss of single electron from a non- radical or by the gain of a single electron by a non-radical. They can easily be formed when a covalent bond is broken if one electron from each of the pair shared remains with each atom, this mechanism is known as hemolytic fission. In water, this process generates the most reactive species, hydroxyl radical $\mathrm{OH}^{-}$(Halliwell and Chirico, 1993). From the forgoing, this study investigated the comparative study of the Effects of aqueous and ethanolic Extracts of the G. latifolium and $O$. gratissimum on the invivo Antioxidants level of male Wistar Albino Rats.

\section{MATERIALS AND METHOD}

\section{Collection and preparation of plant sample}

The leaves of $O$. gratissimum and $G$. latifolium were collected fresh from the local Ochanga market around Onitsha, Anambra state and identified by Dr. A. Akinnibosun in the Department of Botany, University of Benin, Edo State, dried and stored in an air tight, opaque, well-sealed container to avoid the destruction of the vitamins by sunlight dried leaves of the plants were coarsely powdered and weight taken. The $O$. gratissimum $700 \mathrm{~g}$ and G. latifolium $700 \mathrm{~g}$ of the powdered materials were soaked in one litre of ethanol and water respectively in a glass container with a plastic screwed cap and kept in a refrigerator for 48 hours at $4^{\circ} \mathrm{C}$. The extracts were filtered and distilled on a water bath. The last traces of the solvent were evaporated under reduced pressure in rotary evaporator.

\section{Feeding and administration of experimental animals}

Forty two (42) male albino wistar rats weighing between 160$250 \mathrm{~g}$ were obtained from the animal House of Anatomy, University of Benin. The animals were housed in a wellventilated cages (wooden bottom and wire mesh top) where bedding was replaced every two (2) days and kept under controlled environment (room temperature of about $27{ }^{\circ} \mathrm{C}$ and 12 hours light/dark cycle). They were allowed to acclimatize for two (2) weeks and fed growers mash and water from tap ad libitum.

The rats were divided randomly into seven (7) groups of six (6) rats each.

Group 7served as the control group while groups1, 2, 3, 4, 5 and 6 served as the test groups.

Group 1: This group received $200 \mathrm{mg} / \mathrm{kg}$ body weight of the aqueous extract of $O$. gratissimum.

Group 2: This group received $200 \mathrm{mg} / \mathrm{kg}$ body weight of ethanol extract of $O$. gratissimum.

Group 3: This group received $200 \mathrm{mg} / \mathrm{kg}$ body weight of aqueous extract of $G$. latifolium.

Group 4: This group received $200 \mathrm{mg} / \mathrm{kg}$ body weight of ethanol extract of $G$. latifolium.

Group 5: This group received $400 \mathrm{mg} / \mathrm{kg}$ body weight of aqueous extracts of both $O$. gratissimum and $G$. latifolium.

Group 6: This group received $400 \mathrm{mg} / \mathrm{kg}$ body weight of ethanolic extracts of both $O$. gratissimum and G. latifolium.

The extracts was administered via oral gastric intubation at a dose of $200 \mathrm{mg} / \mathrm{kg}$ body weight for single extract treatment and $400 \mathrm{mg} / \mathrm{kg}$ body weight combined extract treatment daily. The dosage of the extract use were according to the method of Sonia and Scrinvasan (1999) and Ebong et al., (2006). The control group was given growers mash and water without treatment. The treatment lasted for 28 days (4 weeks).

\section{Preparation of Serum}

The male rats were sacrificed at the $28^{\text {th }}$ day using light chloroform. The blood were taken using syringes of $5.0 \mathrm{ml}$ into test tubes and allowed to stand for 30 min clotting time. It was then centrifuged at $8000 \mathrm{xg}$ for $10 \mathrm{~min}$. and the supernatant collected and used for the analysis.

\section{Determination of phytochemicals of $O$. gratissimum and} G. latifolium

Determination of alkaloid content was based on the method described by Chang et al., (2002). 
Determination of phenolic content was based on the method described by Siddhuraju and Beeker (2003).

Determination of flavonoid content was based on the method described by Zhishen et al., (1999).

Determination of tannin content was based on the method described by Siddhuraj and Mancan (2007).

Determination of saponins content was based on the method described by Makkar et al., (2007).

Determination of carotenoids content was based on the method described by Stalikas, (2007).

\section{Acute toxicity study}

Acute toxicity study $\left(\mathrm{LD}_{50}\right)$ was carried out according to the method of Lorke, (1983).The $\mathrm{LD}_{50}$ was carried out according to the method employed by Lorke, (1983). A total of 52 mice, 26 for aqueous and ethanolic extract each of the two plants were used and the study was performed in two phases. In phase 1 , a total of 9 mice was used, they were grouped into 3 groups of 3 mice per group. Group I received $10 \mathrm{mg} / \mathrm{kg}$ extract per oral administration. Group 2 received $100 \mathrm{mg} / \mathrm{kg}$, while group 3 received $1000 \mathrm{mg} / \mathrm{kg}$. The animals were constantly monitored for the next $1 \mathrm{hrs}$, intermittently for the next $3 \mathrm{hrs}$ and finally over 9 period of $24 \mathrm{hrs}$ for mortality and behavioral changes. From result of the first phase, the second phase was carried out. Here a total of 4 mice was employed. They were grouped into 4 groups of one mice per group. Group 1 received $2000 \mathrm{mg} / \mathrm{kg}$, group 2 received $3000 \mathrm{mg} / \mathrm{kg}$, and group 3 received $4000 \mathrm{mg} / \mathrm{kg}$ while group 4 received $5000 \mathrm{mg} / \mathrm{kg}$. The animals were monitored as in phase, for mortality and behavioral changes.

\section{Biochemical Analysis for Enzymatic Antioxidant}

Estimation of malondialdehyde was carried out by the method of Hunter et al., (1963), modified by Gutteridge and Wilkins (1950).

Estimation of superoxide dismutase (SOD) content was by the method of Misra and Fridovich (1972).

Estimation of catalase activity was by the method of Cohen et al., (1970).

Estimation of glutathione peroxide was by the method of Flohe and Gunzler method (1984).

Estimation of total protein was by the method of Weichselbaum, (1946).

\section{Determination of Non-Enzymatic Antioxidant Activity}

Estimation of vitamin C (ascorbic acid) content was by the method of Omaye et al. (1979).

Estimation of vitamin E (alpha tocopherol) content was by the method of Desai (1984).

\section{Statistical Analysis}

All data were expressed as mean \pm SD (and one way ANOVA used for the analysis of variance using IBM SPSS Version 21.Values were compared to control and $\mathrm{p}<0.05$ was regarded as significant (Woodson, 1987).

\section{RESULTS}

The result obtained in the determination of $\mathrm{LD}_{50}$ for rats fed with aqueous extract was presented in Table 1.

Table 1: The $\mathrm{LD}_{50}$ result of aqueous extracts of $O$. gratissimum and G. latifolium leaf.

\begin{tabular}{llll}
\hline Phases & $\begin{array}{l}\text { Doses } \\
(\mathrm{mg} / \mathrm{kg})\end{array}$ & $\begin{array}{l}\text { Number of } \\
\text { rats/Number } \\
\text { of animals }\end{array}$ & behavioral \\
\hline 1 & 10 & $0 / 3$ & Normal \\
& 100 & $0 / 3$ & Normal \\
& 1000 & $0 / 3$ & Normal \\
& 2000 & $0 / 1$ & Normal \\
& 3000 & $0 / 1$ & Normal \\
& 4000 & $0 / 1$ & Normal \\
& 5000 & $0 / 1$ & Normal \\
\hline
\end{tabular}

The result obtained in the determination of $\mathrm{LD}_{50}$ for rats fed with ethanolic extract was presented in Table 2.

Table 2: The toxicity dose (LD50) result of ethanolic extracts of O. gratissimum and G. latifolium.

\begin{tabular}{llll}
\hline Phases & $\begin{array}{l}\text { Doses } \\
(\mathrm{mg} / \mathrm{kg})\end{array}$ & $\begin{array}{l}\text { Number of } \\
\text { rats/Number } \\
\text { of animals }\end{array}$ & behavioral \\
\hline 1 & 10 & $0 / 3$ & Normal \\
& 100 & $0 / 3$ & Normal \\
2 & 1000 & $0 / 3$ & Normal \\
& 2000 & $0 / 1$ & Normal \\
& 3000 & $0 / 1$ & Normal \\
& 4000 & $1 / 1$ & Calm \\
& 5000 & $1 / 1$ & Calm \\
\hline
\end{tabular}

Phytochemical analysis results of ethanolic and aqueous extracts of G. latifolium was presented in Table 3, 4 and 5.

Table 3: Preliminary phytochemical screening of ethanolic and aqueous extracts of $\mathrm{G}$. latifolium

\begin{tabular}{lcc}
\hline Phytochemical & Ethanolic extract & aqueous extract \\
\hline Reducing Sugar & + & ++ \\
Polysaccharides & + & ++ \\
Glycosides & + & + \\
Saponins & + & ++ \\
Phenolics & ++ & + \\
Flavonoids & + & + \\
Tanins & + & - \\
Steroids & ++ & - \\
Terpenoids & - & + \\
Alkaliods & ++ & + \\
\hline
\end{tabular}

Key: - = Absent; + = present, ++= Highly present. 
Table 4: Preliminary phytochemical screening of ethanolic and aqueous extracts of $\mathrm{O}$. gratissimum

\begin{tabular}{lcc}
\hline Phytochemical & Aqueous Extract & Ethanolic Extract \\
\hline Reducing sugar & + & + \\
Polysaccharides & + & + \\
Glycosides & ++ & + \\
Saponins & ++ & + \\
Phenolics & - & + \\
Flavonoids & + & ++ \\
Tanins & + & + \\
Steroids & - & - \\
Terpenoids & - & - \\
Alkaliods & + & + \\
\hline
\end{tabular}

Key: - = Absent; + = present, $++=$ Highly present.

Table 5: Comparative quantitative result of the phytochemicals found in ethanolic and aqueous extracts of $\mathrm{O}$. gratissimum and G. latifolium.

\begin{tabular}{lllll}
\hline $\begin{array}{l}\text { Phytochemicals } \\
(\%)\end{array}$ & $\mathrm{A}_{1}$ (aqueous) & $\mathrm{A}_{2}$ (ethanol) & $\mathrm{B}_{1}$ (aqueous) & $\mathrm{B}_{2}$ (ethanol) \\
\hline Alkaliods & 2.43 & 5.03 & 0.36 & 2.47 \\
Flavonoids & 1.84 & 3.92 & 2.83 & 10.18 \\
Saponins & 7.47 & 2.08 & 9.07 & 6.82 \\
Tannins & - & 0.49 & 1.03 & 4.84 \\
Phenolics & 3.87 & 10.74 & - & 0.48 \\
Glycosides & 0.84 & 3.79 & 5.21 & 0.73 \\
Steroids & - & 8.43 & - & - \\
Terpenoids & 0.34 & - & - & - \\
Reducing sugar & 4.11 & 0.87 & 7.84 & 6.08 \\
Polysaccharides & 6.31 & 1.88 & 10.34 & 6.77 \\
\hline
\end{tabular}

$\mathrm{A}_{1}$ is the aqueous extract of $G$. latifolium, $\mathrm{A}_{2}$ is the ethanolic extract of $G$. latifolium, $\mathrm{B}_{1}$ is the aqueous extract of $O$. gratissimum, $\mathrm{B}_{2}$ is the ethanolic extract of $O$. gratissimum.

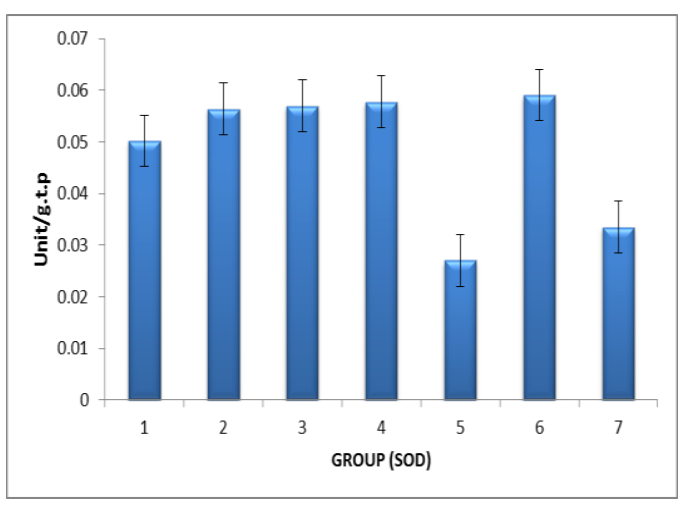

Figure 1: The SOD activity in rats for different groups used in the study.

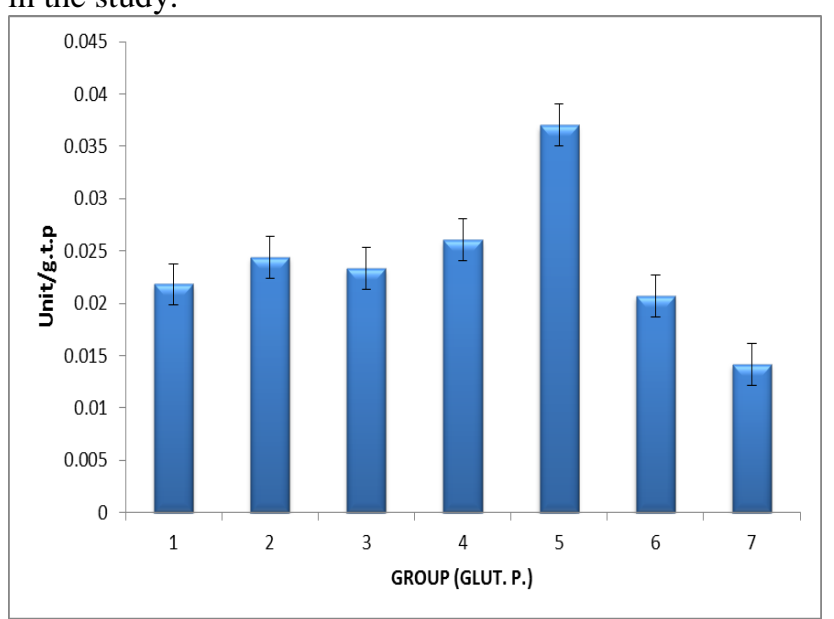

Figure 2: The glutathione peroxidase activity in rats for different groups used in the study.

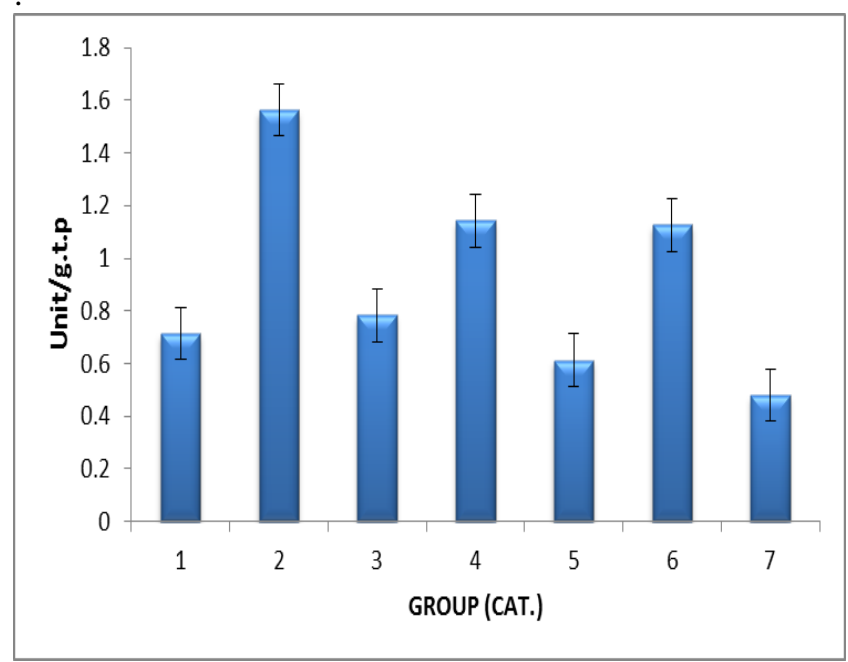

Figure 3: The activity of catalase in rats for different groups used in the study.

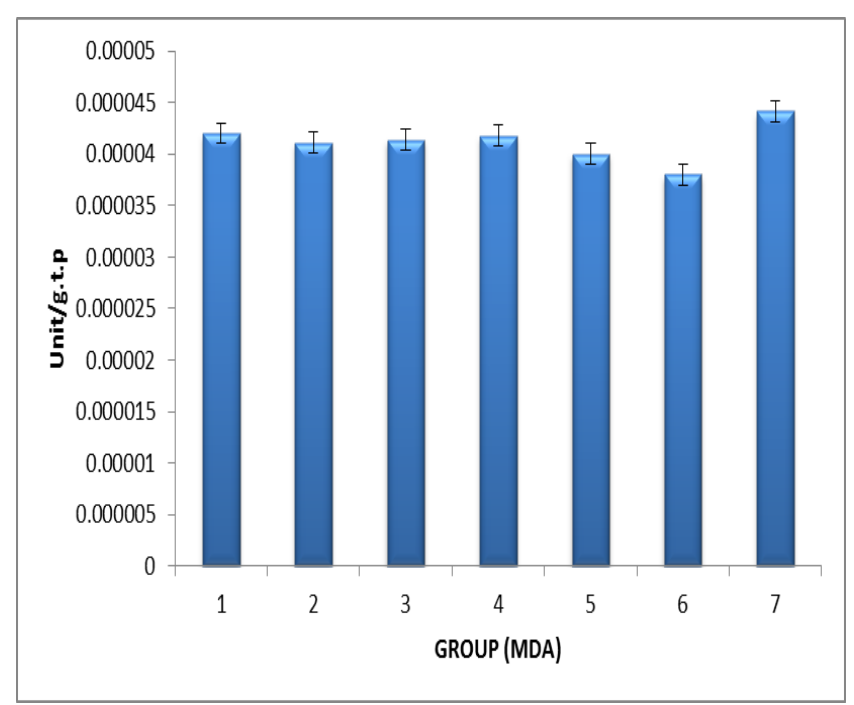

Figure 4: The activity of malondialdehyde in rats for different groups used in the study.

The result presented in Table 6 shows a comparative result obtained from one-way ANOVA for both enzymatic and non-enzymatic antioxidants.

\section{DISCUSSION}

The $\mathrm{LD}_{50}$ by oral administration carried out with the method of lorke, (1983) showed that the lethal dose for aqueous and the ethanolic extracts of $O$. gratissimum was greater than $5000 \mathrm{mg} / \mathrm{kg}$ and that of the aqueous and ethanolic extracts of G. latifolium was $3400 \mathrm{mg} / \mathrm{kg}$ (Table 1 and 2). Results obtained from the phytochemical analysis (Table 3, 4 and 5) revealed that phenols, flavonoids, alkaloids were higher in the ethanolic extracts of the leaf samples than that of aqueous extracts. This could be because they are more soluble in ethanol than water. 
Table 6: Comparative results of the enzymatic and non-enzymatic antioxidants

\begin{tabular}{|c|c|c|c|c|c|c|}
\hline GP & $\begin{array}{l}\text { SOD } \\
\text { Unit/g. }\end{array}$ & $\begin{array}{l}\text { GLUT. P. } \\
\text { unit/g. }\end{array}$ & $\begin{array}{l}\text { CAT. } \\
\text { unit/g. }\end{array}$ & $\begin{array}{l}\text { MDA } \\
\text { unit/g. }\end{array}$ & $\begin{array}{l}\text { VIT.E } \\
\mathrm{Mg} / \mathrm{dl}\end{array}$ & $\begin{array}{l}\text { VIT. C } \\
\mathrm{Mg} / \mathrm{ml}\end{array}$ \\
\hline 1 & $\begin{array}{l}0.05 \\
\pm 0.00\end{array}$ & $\begin{array}{l}0.02 \\
\pm 0.00\end{array}$ & $\begin{array}{l}0.71 \\
\pm 0.16\end{array}$ & $\begin{array}{l}0.00 \\
\pm 0.00\end{array}$ & $\begin{array}{l}567 \\
\pm 46\end{array}$ & $\begin{array}{l}0.03 \\
\pm 0.02\end{array}$ \\
\hline 2 & $\begin{array}{l}0.06 \\
\pm 0.01\end{array}$ & $\begin{array}{l}0.02 \\
\pm 0.00\end{array}$ & $\begin{array}{l}1.56 \\
\pm 0.28\end{array}$ & $\begin{array}{l}0.00 \\
\pm 0.00\end{array}$ & $\begin{array}{l}578 \\
\pm 68\end{array}$ & $\begin{array}{l}0.02 \\
\pm 0.00\end{array}$ \\
\hline 3 & $\begin{array}{l}0.06 \\
\pm 0.00\end{array}$ & $\begin{array}{l}0.02 \\
\pm 0.00\end{array}$ & $\begin{array}{l}0.78 \\
\pm 0.24\end{array}$ & $\begin{array}{l}0.00 \\
\pm 0.00\end{array}$ & $\begin{array}{l}524 \\
\pm 88\end{array}$ & $\begin{array}{l}0.02 \\
\pm 0.00\end{array}$ \\
\hline 4 & $\begin{array}{l}0.06 \\
\pm 0.01\end{array}$ & $\begin{array}{l}0.03 \\
\pm 0.00\end{array}$ & $\begin{array}{l}1.14 \\
\pm 0.59\end{array}$ & $\begin{array}{l}0.00 \\
\pm 0.00\end{array}$ & $\begin{array}{l}589 \\
\pm 59\end{array}$ & $\begin{array}{l}0.02 \\
\pm 0.00\end{array}$ \\
\hline 5 & $\begin{array}{l}0.03 \\
\pm 0.00\end{array}$ & $\begin{array}{l}0.04 \\
\pm 0.00\end{array}$ & $\begin{array}{l}0.61 \\
\pm 0.29\end{array}$ & $\begin{array}{l}0.00 \\
\pm 0.00\end{array}$ & $\begin{array}{l}462 \\
\pm 49\end{array}$ & $\begin{array}{l}0.02 \\
\pm 0.00\end{array}$ \\
\hline 6 & $\begin{array}{l}0.06 \\
\pm .001\end{array}$ & $\begin{array}{l}0.02 \\
\pm 0.00\end{array}$ & $\begin{array}{l}1.13 \\
\pm 0.14\end{array}$ & $\begin{array}{l}0.00 \\
\pm .00\end{array}$ & $\begin{array}{l}523 \\
\pm 237\end{array}$ & $\begin{array}{l}0.02 \\
\pm 0.00\end{array}$ \\
\hline 7 & $\begin{array}{c}0.03 \\
\pm .001\end{array}$ & $\begin{array}{l}0.01 \\
\pm 0.00\end{array}$ & $\begin{array}{l}0.48 \\
\pm-0.19\end{array}$ & $\begin{array}{l}0.00 \\
\pm .00\end{array}$ & $\begin{array}{l}508 \\
\pm 52\end{array}$ & $\begin{array}{l}0.02 \\
\pm 0.00\end{array}$ \\
\hline
\end{tabular}

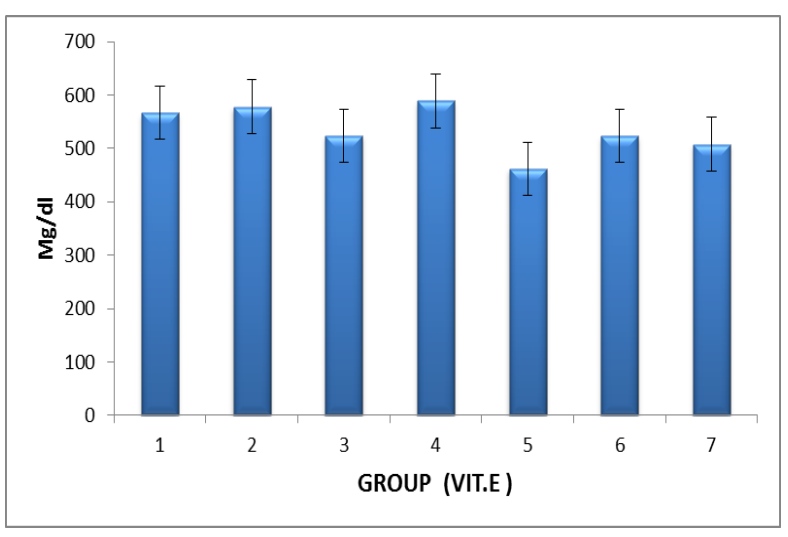

Figure 5: The concentration of vitamin $\mathrm{E}$ in rats for different groups used in the study.

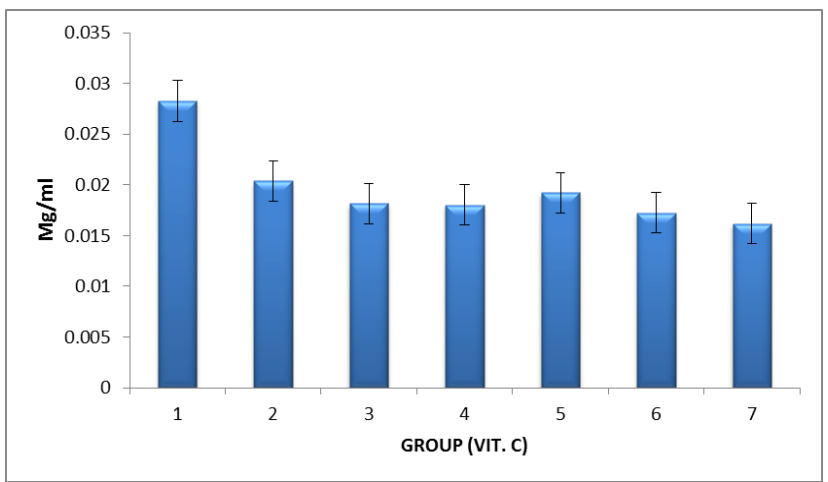

Figure 6: The vitamin c concentration in rats for different groups used in the study.
Again, saponins, reducing sugars and polysaccharides were high in the aqueous extracts than in the ethanolic extracts. The aqueous extract of $G$. latifolium leaf contained more quantity of the phytochemicals like flavonoids, saponins, tannins, glycosides, reducing sugar, polysaccharides than that of $O$. gratissimum. This is in agreement with that reported by Morebise et al., (2002), who reported that aqueous extract of $G$. latifolium contained more phytochemicals than $O$. gratissimum.

Results obtained from the antioxidant analysis effects on superoxide dismutase (SOD) activity (Table 6) revealed that rats fed with aqueous and ethanolic extracts of the individual leaf samples exhibited higher activity at $p<0.05$ than the control (Fig. 1). The ethanolic and aqueous extract of the biherbal mixture of both plant extracts fed to rats in groups 5 and 6 have higher activity than the mono-herbal aqueous and ethanolic extract of each of the extracts fed to rats in groups $1,2,3$ and 4. From the SOD analysis, it shows that the ethanolic extracts are more effective than the aqueous extracts of either plants. This is in agreement with that reported by Ugochukwu et al. (2003), who suggested that ethanolic extracts are more effective than the aqueous extracts on SOD. The analysis also shows that extracts of $G$. latifolium is more effective than $O$. gratissimum.

In the glutathione peroxidase (GLUT.P) assay (Fig. 2), there were significant glutathione peroxidase activities compared to the control. The mean glutathione peroxidase concentration of group 2 was not significantly higher than group 1 when compared to group 7. In the group 3 fed with the aqueous extract of $G$. latifolium and group 4 fed the ethanolic extract of $G$. latifolium, the mean glutathione 
peroxidase value of group 4 was significantly higher than group 3 when compared to group 7. In the group 5 fed with the aqueous extract of $G$. latifolium with $O$. gratissimum and group 6 fed the ethanolic extract of $G$. latifolium with $O$. gratissimum leaf, the mean glutathione peroxidase concentration of group 5 was significantly higher than group 6 when compared to group 7 . Here, the result shows that ethanolic mono-herbal formula of either plant was more effective than its aqueous mono-herbal formula of either plant. Again, the ethanolic bi-herbal formula of G. latifolium and $O$. gratissimum fed to rats in group 6 was low in activity compared to groups 2, 3, 4 and 5 fed aqueous mono-herbal formula, ethanolic mono-herbal formula, aqueous monoherbal formula and bi-herbal formula respectively. This shows that there could be complication resulting from herbal combination. This is in line with the report of Nwanchukwu and Iweala (2014). They reported similar result in their publication.

In catalase (CAT) analysis (Fig. 3), rats fed with the various concentrations of the both plant extracts (aqueous and ethanolic) and bi-herbal extracts exhibited a significant higher activities than the control which is group 7 . In the group 1 fed the aqueous extract of $O$. gratissimum and group 2 fed the ethanolic extract of $O$. gratissimum, the mean catalase (CAT) values of group 2 was significantly $(p<0.05)$ higher than group 1 when compared to the control. In the group 3 fed the aqueous extract of $G$. latifolium and group 4 fed the ethanolic extract of $G$. latifolium, the mean catalase (CAT) values of group 4 was not significantly higher than group 3 when compared to group 7 . The effect of the various extracts on the activity of malondialdehyde in rats for different groups (Fig. 4) indicates that there were less malondialdehyde in the various groups to compare with control. This is an indication of antioxidant activities in preventing lipid peroxidation.

Analysis involving vitamin E revealed that rats fed with the various concentrations of extracts of both plant extracts shows that they were not significantly higher than the control which is group 7 (Fig. 5). In the group 1 fed with aqueous extract of $O$. gratissimum and group 2 fed the ethanolic extract of $O$. gratissimum, the mean concentration of vitamin E of group 2 was not significantly higher than group 1 when compared to group 7. In the group 3 fed with aqueous extract of $G$. latifolium and group 4 fed with ethanolic extract of $G$. latifolium, the mean concentration of vitamin $\mathrm{E}$ concentration of group 4 was not significantly higher than group 3 when compared to group 7. In the group 5 fed the aqueous extract of $G$. latifolium with $O$. gratissimum and group 6 fed the ethanolic extract of $G$. latifolium with $O$. gratissimum, the mean concentration of vitamin $\mathrm{E}$ of group 6 was not significantly higher than group 5 when compared to group 7 . From this analysis, there is suggestion that the ethanolic extract of the plant are more effective than the aqueous extract of the plants. Again, the aqueous extracts bi-herbal combination of $O$. gratissimum and $G$. latifolium seem to be less effective than the ethanolic extracts bi-herbal combination of $O$. gratissimum and G. latifolium. From this, it could be suggested that the aqueous bi-herbal combination of $O$. gratissimum and $G$. latifolium is less effective in enhancing the activity of vitamin $E$ than the mono-herbal aqueous and ethanolic of each plant. This could result from complication of the combined plant extract. This is in line with the report of Nwanchukwu and Iweala, (2014). They reported similar result in their work.

In vitamin $\mathrm{C}$ analysis, rats fed with the various extracts revealed that Vitamin $C$ concentrations were not significantly higher than the control which is group 7 (Fig. 6). In the group 1 , rats fed the aqueous extract of $O$. gratissimum and group 2 fed with ethanolic extract of $O$. gratissimum, the mean concentration of vitamin $\mathrm{C}$ of group 1 was not significantly higher than group 2 when compared to group 7 . In the group 3 fed with aqueous extract of $G$. latifolium and group 4 fed with ethanolic extract of $G$. latifolium, the mean concentration of vitamin $\mathrm{C}$ concentration of group 3 was not significantly higher than group 4 when compared to group 7 . In the group 5 fed the aqueous extract of $G$. latifolium with $O$. gratissimum and group 6 fed with ethanolic extract of $G$. latifolium with $O$. gratissimum, the mean concentration of vitamin c of group 5 was not significantly higher than group 6 when compared to group 7. From this analysis, it could be suggested that the vitamin $\mathrm{C}$ ethanolic extracts of the plants are less effective than the vitamin $\mathrm{C}$ aqueous extract of the plants. This could be that the aqueous extract of the plant contain phytochemicals that support the activity of vitamin C. This is in line with the report of Halvoresen et al., (2006), who reported similar observation. Again, the aqueous extract of bi-herbal combination of $O$. gratissimum and G. latifolium seem to be more effective in supporting the vitamin c activity than the ethanolic extracts bi-herbal combination of $O$. gratissimum and G. latifolium and so, it could be suggested that $O$. gratissimum have more potential of enhancing the vitamin c activity. It is clear that invivo antioxidant enzymes like superoxide dismutase, catalase and the glutathione peroxidase are more effective when present in the ethanolic extract than in aqueous extract but the reverse is the case when it comes to non-enzymatic antioxidants like vitamin $\mathrm{C}$ and $\mathrm{E}$.

\section{CONCLUSION}

The result reveals that the ethanolic extracts of $O$. gratissimum, and G. latifolium were more active increasing the enzymatic and non-enzymatic antioxidants than the aqueous extract of the two leaves. The bi-herbal extract of both leaves shows higher activity on the enzymatic and nonenzymatic antioxidants than the mono-herbal formula of either leaves when fed to the rats. An extension of this work needs to be carried out to determine the toxicity level of the bi-herbal extract on animal and human subjects. 


\section{REFERENCES}

Akinmoladum, A.C., Ibukun, E.O., Emmanuel, A., Obuotor. E.M. and Farombi, E.O. (2007). Phytochemical constituent and autioxidant activity of extract from the leaves of Ocimum gratissimum. Science Research Essay, 2:163 - 166.

Cohen, G, Dembiec, D. and Marcus, J. (1970). Measurement of catalase activity in tissue extracts, Ann. Biochem., 34:30-38.

Desai, I.D. and Scott, M I. (1965). Mode of action of selenium in relation to biological activity of tocopherols. Arch Biochem, Biophys. 110:309-315.

Edeogra, H.O., Eriata, D.O. (2001). Alkaloids, Tannins and contents of some Nigeria medical plant. Journal of medical aromatic plants science, 23:21-25.

Ervanshings, G. (1980). The chemical constituent of Ocimun gratissimun. Doki Tskha, 244; (2) 72-77.

Flohe, L. and Gunzler, W.A (1984). Assey of glutathione perioxidase. Method Enzymol.105:114-121

Gutteridge, J.M. and Wilkins, S (1982). Copper dependent hydroxyl radical damage to ascorbic acids formation of a thiobarbituric acid-reactive product. Febs., Lett., 137:327-340

Halliwell, B., and Chirico, S. (1993). Lipid peroxidation: Its mechanism, measurement, and significance. Am. J. Clin. Nutr.57:715S-725S.

Halvoresen, B.L, Carlsen, M.H., Philips, K.M., Bohn, S.K., Holte,K., Jacobs, D.R. (2006). Content of redox active compound in food consumed in the U.S.A, America. Clin. Nutri, 84(1)95-135.

Hunter F.E., Gebicki, J.M., Hoffretein, P.E., Weistein, J. and Scott, A. (1963). Swelling and lysis of rat liver mitochondria induced by ferrous ions. J. Biol. Chem. 238:828-835.

Ijeh, I.I., Njoku, O.U. and Ekenze, E.C. (2004). Medicinal evaluation of Xylopia aethiopica and Ocimiun gratissimun. $J$ Med. Aromatic plant Sci., 26:19-21

Lorke, D. (1983). Anew approach to practical acute toxicity testing. Arch Toxicol., 54:275-287.

Misra, H.P. and Fridowich, I. (1972). The role of superoxide anion in the autoxidation of epinephrine and a simple assay for superoxide dismutase. J.Biol. Chem. 247(10):3170-3175.

Morebise, O., Fafunso, M. A, Makinde, I .M., Olafide, O.A., Awe, E.O., (2002). Antiinflammatory properties of leaves of Gongrenema latifolium.Phytother.Res.16(1):575-577
Nwanchukwu, N and I weala, E.E.J. (2014). Evaluation the oxidative stress status of albino rat fed with compound spices department of biochemistry school of federal university of technology. Asian Journal of Agriculture and Food Science, 2:153-156

Ogundipe, O.O, Moody,S.O., Akinyemi,T.O. and Reiman, A., (2003). Hypoglycemic potential of methanolic extracts of selected plant food in alloxanized mice plant foods. Human Nutrition, 58: 1-7.

Omaye, S.T. and Saubeclich, H.E. (1979). Selected method for the determination of ascorbic acid in animals cell and tissue and fluid. Method Emzymol,IncAcademic press, New York, 62:311

Schneider, C., Rotscheidt, K. and Breitmaier, E. (1993). A New pregnanes glycosides from Gongronema latifolium.Liebigs analarder chemie., 10:1057-1062

Ugochukwu, N.H., Babady, N.H., Cobourn, M., Gasset, R.S. (2003). The effect of Grongonema latifolium extracts on serum lipid profile and oxidative steps in hepatocytes of diabetic albeno rat. J. Biol., Sci., 20:1-5.

Weichselbaum. T.E. (1946). Total protein analysis. Amer. J. Clin. Path., 16:40- 41.

Woodson, R.F. (1987). Statistical method for analysis of Biochemical data, probability and mathematical statistics. Wiley chichester, London.

\section{$\underline{\text { How to cite this article }}$}

Okoli, P., Nwaka, A.C., Anene, I.N. (2017). Comparative Studies of the Aqueous and Ethanolic Extracts of Ocimum gratissimum and Gongronema latifolium Leaves on the invivo Antioxidant levels of Wistar Albino Rats. Tropical Journal of Applied Natural Sciences, 2(1): 54-60. Doi: https://doi.org/10.25240/TJANS.2017.2.1.09. 